\title{
Development of Physical Education Teaching Model Section at Lower Class of Primary School Using TPSR
}

\author{
Tri Nurharsono ${ }^{1}$, Tandiyo Rahayu ${ }^{2}$, Sulaiman $^{3}$, Mugio Hartono ${ }^{4}$ \\ \{trinurharsono@yahoo.co.id\} \\ Universitas Negeri Semarang ${ }^{1,2,3,4}$
}

\begin{abstract}
There are obstacles faced by teachers in learning process of physical education in lower grade of elementary school. One of them deals with textbook. It is important to investigate how physical fitness material in elementary school is taught by using TPSR. The purpose of this study is to reveal and produce physical education product development models by using TPSR. This study employed Brog and Gall's method. The results showed the game experts were $98.43 \%$; expert learning 1 was $92.5 \%$; expert learning 2 was $90 \%$; and expert learning 3 was 95\%. Affective aspects were elevated from level 0 and 1 . After playing postal triangle using TPSR approach to level 2 and 3, cognitive and psychomotor aspects were $80 \%$ and $79.50 \%$ respectively. Based on the data of attitude, knowledge, and skill, TPSR is able to stimulate students' characters conveying material and provide literacy through attractive visual media which is easy to understand.
\end{abstract}

Keywords: learning model, physical fitness, TPSR

\section{Introduction}

There are many obstacles faced by teachers related to learning process, especially in elementary schools such as the quality of teacher and student textbooks. There is a mismatch between basic competencies in the curriculum and the materials in the teacher and student textbook. Consequently, the materials seem superficial. Then, the contents cannot be used as a whole learning guide because the description is not sharp enough, and many problems arise in the field. Learning environment is carefully regulated to improve the growth and development of the entire realm, physical, psychomotor, cognitive, and affective of each student. ${ }^{1}$

The purpose of physical education is to develop attitudes or characters, knowledge, and skills. In this case, the researcher will develop physical fitness material with TPSR (Teaching Personal and Social Responsibility) model to the basic classroom learning process. TPSR Model has a strong foundation in humanism to create a student-centered approach with the aim of facilitating the development of personal and environmental responsibilities. Physical fitness is actually one aspect of total fitness because total physical fitness includes physical fitness, mental fitness, social fitness, and emotional fitness. The unique characteristic of this model lies in focusing on setting daily goals for the participation of students in the class. An important aspect of this model is to encourage students to be more reflective in making decisions and provide access for students to express opinions, interests, in their feelings. ${ }^{2}$

${ }^{1}$ Samsudin. Pembelajaran Pendidikan Jasmani Olahraga dan Kesehatan. Jakarta : Litera (2008)

${ }^{2}$ Donald R. Hellison. Goal and Strategies for Teaching Physical Education. Champaign, Illinois: Human Kinetics Publisher, Inc (1985) 
Physical fitness includes a complex understanding, which includes several components. Thus, someone is said to be in a good condition when he/she has good physical fitness components such as strength, explosive power, endurance, agility, balance, speed, coordination, flexibility, accuracy, and speed reaction. ${ }^{3}$

Character education is the creation of a school environment that helps students in the development of ethics, responsibility through models, and teaching good character through universal values. These character values should be instilled so that the students are able to apply in their lives both in their families, schools, communities and countries so that they can make a positive contribution to their environment. ${ }^{4}$

The objectives of this study are a) to produce a product for the elementary school class in terms of physical fitness material learning model with TPSR approach according to the basic competencies of 2013 Curriculum and b) to investigate physical education learning in planting attitudes through role play game such as leadership collaboration responsibility that can shape students' characters in daily life.

\section{Research Methodologgy}

The education needs to be adjusted to the level of development. In choosing an approach, the learning model and method must be appropriate so that the aim of education can be achieved thoroughly. In the process of learning physical education in elementary school, an approach is needed to achieve completeness in student learning outcomes because the right approach will be able to achieve the learning objectives.

TPSR comprises several levels. As a cumulative development, learners learn that each level is built and covers all the lower levels. The new level, Level Zero, represents irresponsible attitudes and behavior. Level 1 is respect for the rights and feelings of others without much participation in learning activities. Level II describes participants participating in the supervision of education as cooperative and respecting other children's rights and feelings. Level III represents someone who respects participation and is present. The following are five levels of students (Hellison and Martinek, 2006) ${ }^{5}$.

a. Zero level, irresponsible students operating at Level Zero make excuses, blame others for their behavior, and refuse personal responsibility for what they do or fail to do.

b. Level I, Sincerely

Students at level I may not participate in daily activities or show a lot of research or improvement, but they are able to control their behavior by not using the rights of other students to teach. Their behavior is not always known by the teacher and without continuous supervision.

c. Level II, Participation

Level II learners not only show at least a little respect for others but also willingly play, accept challenges, practice motor skills, and practice fitness under the supervision of a teacher.

\footnotetext{
${ }^{3}$ Soegiyanto, and Sudjarwo. Perkembangan dan Belajar Gerak. Jakarta: Depdikbud (1993)

${ }^{4}$ Maunah, B. Implementasi Pendidikan Karakter dalam Pembentukan Kepribadian Holistik Siswa. Jurnal Pendidikan Karakter (2015)

${ }^{5}$ Hellison D \& Martinek T. Social and individual responsibility programs. In D Kirk, D Mac-donald, $\&$ M O'Sullivan (Eds.), The handbook of physical education(pp. 610-626). Thousand 401Oaks, CA: Sage (2006)
} 


\section{d. Level III, Self-Direction}

Level III students not only show respect and participation but are also able to work without supervision without direct supervision. They can identify their own needs and start planning them.

e. Level IV, Care.

Students at level IV, aside from respecting others, participating, and being self-directed, are motivated to broaden their sense of responsibility outside of themselves by working together, giving support, showing care and help.

\section{Results and Discussion}

This product is in the form of a guidebook of teaching physical education on physical fitness material to facilitate students in exploring and understanding the contents of the book. Besides, the product is also displayed in CD or DVD. This study will develop several products in the form of physical education learning on physical fitness material for lower grade elementary school students with TPSR approach. The contents of the material are adjusted to the basic competencies in the 2013 curriculum. Since the product is in the form of book, it is easy for elementary students to be able to explore and understand the material with the help of pictures and videos. Students will actively shape and improve character quality with full discipline and responsibility.

\subsection{Small-scale trials}

The product was tested on a small scale in the second-grade students of SD N 02 Gunungpati. Based on the data obtained in the small-scale test, the frequency of student motion which includes affective, cognitive, and psychomotor aspects when performing the Post Triangle game model can be seen in the following figure 1. 


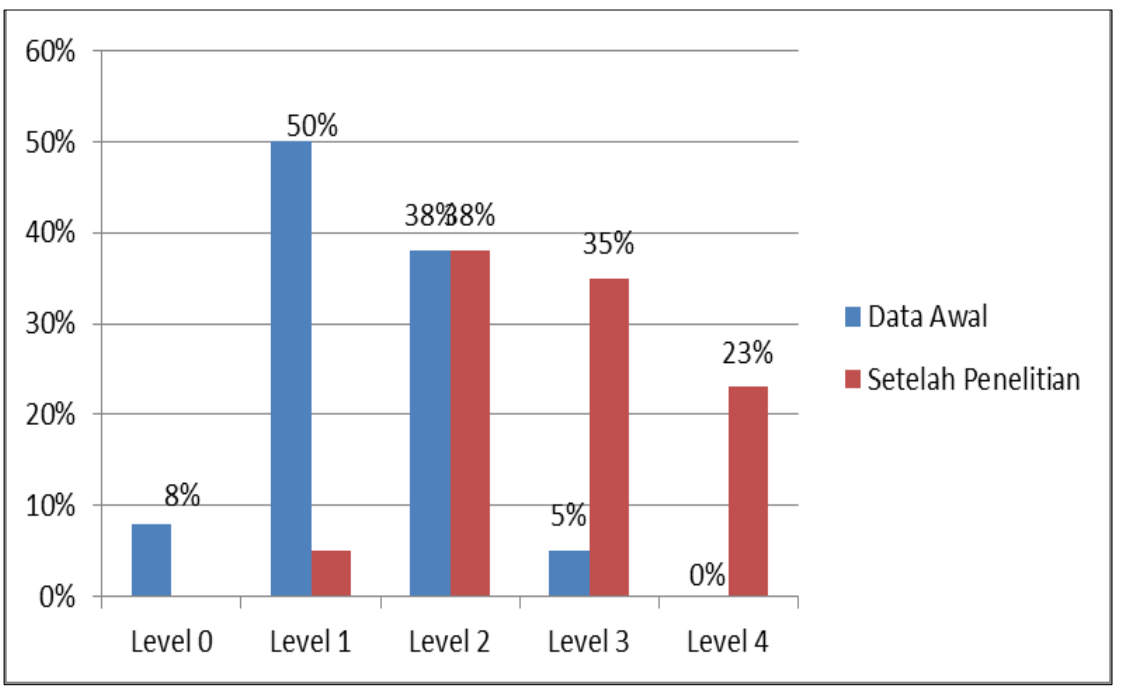

Figure 1. Graph of Affective Observation Data (small scale)

The results of the observation show that the affective aspects consist of 5 levels namely: level 0 , level 1, level 2, level 3, level 4. Based on the figure above, the results can be explained as follows. Level 0 , from the preliminary data before the research, is carried out at of $8 \%$, and it decreases to $0 \%$. Level 1 is initially $50 \%$, and then after a small scale test the percentage decreases to $5 \%$. Level 2, based on the preliminary data and after the exploration, remains at $38 \%$. 4. Level 3, from the data of small scale observations at this level, is 5\%, and it increases to $35 \%$. 5. Level 4 is $0 \%$ and then increases to $23 \%$.

Based on the data of affective observations above after a small-scale trial at SD N 02 Gunungpati, the average percentage of affective students is $75 \%$, which is in 'good' category.

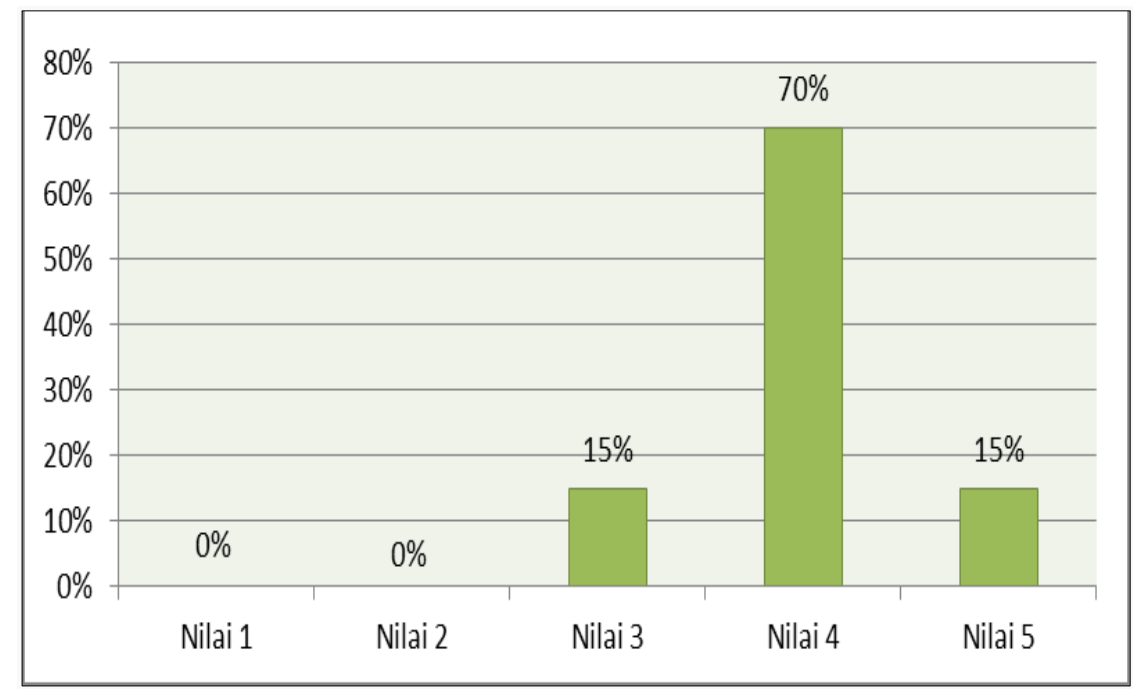

Figure 2. Frequency of Students Score 
There are no students who get score 1 on a small-scale test. None of them get score 2, as well. There are $15 \%$ of the students who get score $3.70 \%$ of the students gain score 4 , and only $15 \%$ of them get score 5 in the small-scale test.

According to the results of cognitive questionnaire, the average percentage is $80 \%$, and the results fall into 'very good' category.

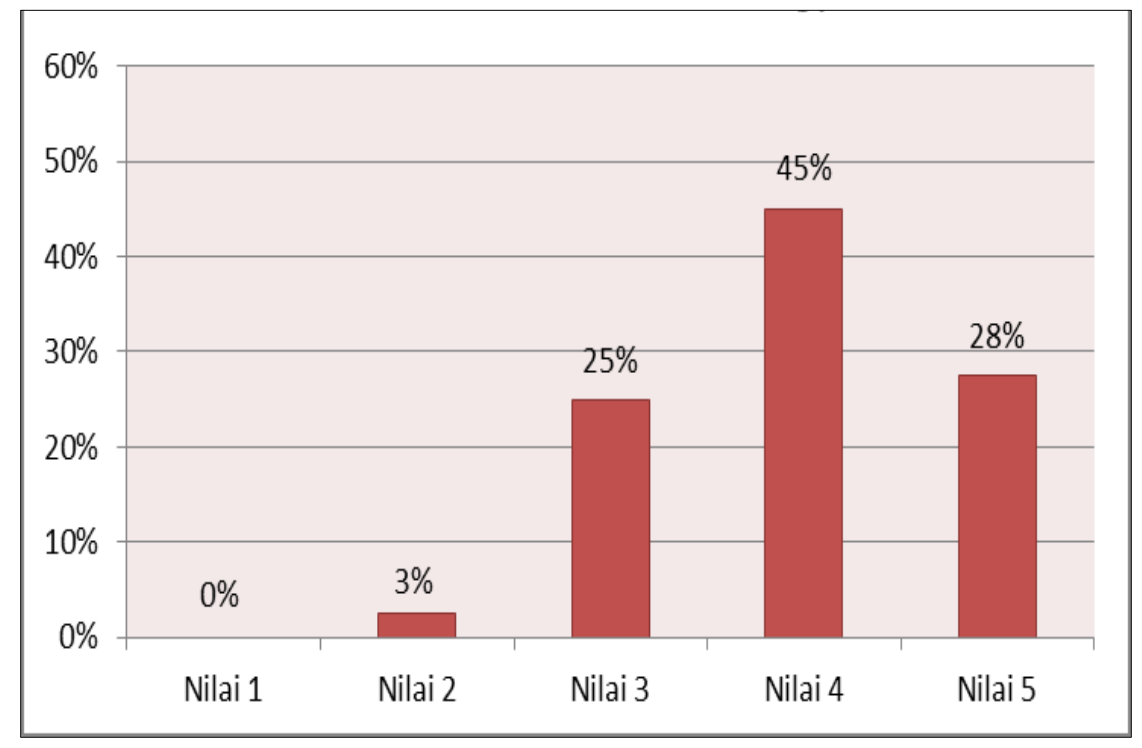

Figure 3. Graph of Psychomotor Observation Data

Score 5 explains that the students can do all the assessment criteria, and there are $28 \%$ of the students who get a score 5. Score 4 explains that the students are able to do 3 of the 4 assessment criteria., and there are $45 \%$ of the students who get score 4 . Score 3 explains that the students are able to do 2 of the 4 assessment criteria, and there are $25 \%$ of the students who get score 3 . Score 2 explains that the students are only able to do 1 of the 4 assessment criteria, and there are $3 \%$ of the students who get score 2 . Score 1 explains that the students cannot answer questions at all, and in this category there is no student who get score 1 . Based on the results of the observations, in the aspect of assessment of physical fitness material, it is obtained an average evaluation percentage of $79.50 \%$ in the postal triangle game. In the psychomotor aspects above it can be concluded that the results of psychomotor assessment of students in small-scale tests falls into 'very good' category.

\subsection{Results of small-scale test data analysis}

Data obtained from small-scale trials at SD N Gunungpati 02 based on affective, cognitive and psychomotor aspects is explained as follows.

Affective aspect. Level 0 shows that the students had no sense of responsibility and could not control themselves. They moved as they wanted, and some students even interfered with their friends eventually leading to fight. Before holding a small-scale trial at SD N 02 Gunugpati, there were 3 students included in level 0 . This was because the students often disturbed their friends during learning process. Then, after a small-scale trial, students who were at level 0 no 
longer existed. This change occured because the students were given a role or task in the Post Triangle game where they are given a responsibility in that role. Thus, they felt that they were appreciated and became more enthusiastic in following the learning process in Post Triangle game.

In level 1, the students already had respect, but in learning activities they still looked passive. At this level, the students did not fully participate in learning. They were more silent and less enthusiastic in learning process. The initial data obtained at SD N 02 Gunugpati showed there were 20 students or $50 \%$ who were at level 1 . Then, after a small-scale test, the percentage decreased to $2 \%$. The decline was due to the fact the students were introduced to a learning model in the form of Triangle Post game to attract the students' attention. 3. In level 2 students participated and dissolved in the game. At this level, the students began to participate in learning process. They were active in following learning process. Preliminary data at this level was 15 students or $38 \%$. After the small-scale trial, the percentage remained $38 \%$. This means the number of students participating and dissolving in the game from the initial data and after smallscale trials had the same results.

In level 3, the students were capable of showing self-direction, meaning that students could control themselves to not disturb their friends, played an active role in the game, and followed the game according to regulations. In the preliminary data, there were 2 students or $5 \%$ in this level, and it increased to $35 \%$ after the small-scale trial. The increase from $5 \%$ to $35 \%$ was due to students being enthusiastic and wanting to try out the role roles that existed in postal triangle games, so that students not only played but also had responsibility and leadership in that role. In level 4 the students already cared about friends and played the game well. The students at this level not just controlled themselves but they were also already at the stage of caring for other people such as justifying a friend who was wrong in doing the move, conditioning members as the group leader does, giving direction to fellow friends. The preliminary data before a small-scale trial was $0 \%$. Then, after a small-scale trial it was found the results of $23 \%$ of students who entered the criteria level 4 or as many as 9 students. The increase is caused by giving roles or tasks in postal triangle games, students who were previously only members of the game, then given the task as postal guards, group leaders or game leaders. This can lead to a child's responsibility, leadership and concern for the learning process.

Cognitive aspect. In score 3, the students were able to answer 2 questions correctly according to the material taught during physical education learning. The students who got 3 grades were 6 or $15 \%$ of the total students. Because the level of students' understanding in analyzing questions differed from one to another, they used more simple sentences so they were able to understand and answer questions correctly. However, the assessment of showed that the students was considered to pass or complete the assessment.

In score 4, the students were able to answer 3 questions correctly. There were 28 students who get a score of 4 or $70 \%$. In this assessment, the students were considered to be able to understand physical fitness material so that they are able to give correct answers. Based on the cognitive assessment instrument, the students were considered to pass or complete the assessment. In score 5 , the students were able to answer 4 questions or more correctly according to the material taught during physical education learning. There were 6 students who got 5 in cognitive assessment or $15 \%$. In this assessment, the students were considered capable of understanding physical fitness material.

Psychomotor aspect. In score 2, the students were only able to do one movement properly and correctly in accordance with basic competencies. There was only a student who got score 2 , this 
was because the students were too active and enthusiastic so that they did not pay attention to how the movements are. This student' movement was too fast, so he forgot the right ones. In value 3 , the students were able to do 2 movements properly and correctly in accordance with basic competencies. On the results of small-scale trials there were 10 students who got score 3 . This was because in learning the students enthusiastically played the game, but there were some points or movements carried out by students which were not in accordance with the criteria of the game. In this case, the students were considered to pass or complete the assessment. 3 .

In value 4 , the students were able to do 3 movements properly and correctly in accordance with basic competencies. There were 18 students who got score 4 . This was because in learning the students played the game enthusiastically, but there were a number of points or movements carried out by students which were not according to the criteria of the game. In this case, the students were considered to pass or complete the assessment. In value 5, the students are able to fulfill 4 movements properly and correctly in accordance with the basic competencies. There were 11 students who got score 5 . The students can make movements in the game well according to the basic competencies of physical fitness. In this case, the students were considered to pass or complete assessment.

\section{Conclusions}

The conclusion of this study is that the researchers will develop a product in the form of a physical fitness material learning model for lower grade elementary school students by using TPSR approach developed for teachers and handbooks for lower grade elementary school students whose contents are adjusted to basic competencies in the 2013 curriculum as well as presentation in books in the form of examples of lower grade elementary school physical fitness material learning model by using TPSR approach. This product is in the form of a guidebook for teaching physical education, especially regarding material physical fitness, to facilitate students in exploring and understanding the contents of the book. Besides, the product is also be presented in CD or DVD. 


\section{References}

[1] Afandi, Muhammad, dkk. Model dan Metode Pembelajaran di Sekolah. Semarang: Sultan Agung Press. (2013).

[2] Doris L. Watson \& Brian D Clocsin, Using Physical Activity and Sport to Teach Personal and Social Responsibility.

[3] Donald R. Hellison. Goal and Strategies for Teaching Physical Education.Champaign, Illinois: Human Kinetics Publisher, Inc. (1985).

[4] Hellison D \& Martinek T. Social and individual responsibility programs. In D Kirk, D Mac-donald, \& M O'Sullivan (Eds.), The handbook of physical education(pp. 610-626). Thousand 401Oaks, CA: Sage. (2006).

[5] Helmiati. Model Pembelajaan. Aswaja Presindo. Yogyakarta. ISBN 13: 978-602-18667-1-9. (2012).

[6] Kemendikbud, Materi pelatihan guru implementasi kurikulum 2013, Tahun 2014, Bugar dan Sehat edisi Olahraga Rekreasi. (2017).

[7] Moeslim, Moch. Kesehatan Olahraga. Jakarta : Fakultas Kedokteran Universitas Indonesia. (1993). [8] Samsudin. Pembelajaran Pendidikan Jasmani Olahraga dan Kesehatan. Jakarta: Litera (2008).

[9] Soegiyanto, and Sudjarwo. Perkembangan dan Belajar Gerak. Jakarta: Depdikbud. (1993).

[10] Maunah, B. Implementasi Pendidikan Karakter dalam Pembentukan Kepribadian Holistik Siswa. Jurnal Pendidikan Karakter. (1). (2015). 